\title{
Regenerative Therapies for Diabetic Microangiopathy
}

\author{
Roberto Bassi, ${ }^{1,2}$ Alessio Trevisani, ${ }^{3}$ Sara Tezza, ${ }^{1}$ Moufida Ben Nasr, ${ }^{4}$ Francesca Gatti, ${ }^{1,2}$ \\ Andrea Vergani, ${ }^{1,5}$ Antonio Farina, ${ }^{6}$ and Paolo Fiorina ${ }^{1,5}$
}

${ }^{1}$ Nephrology Division, Transplantation Research Center (TRC), Children's Hospital, Brigham and Women's Hospital, Harvard Medical School, Boston, MA 02115, USA

${ }^{2}$ DiSTeBA, Università del Salento, 73100 Lecce, Italy

${ }^{3}$ Sorgente Research, 20127 Milan, Italy

${ }^{4}$ Department of Biophysical and Medical Science, Higher Institute of Medical Technology, 1006 Tunis, Tunisia

${ }^{5}$ Department of Medicine, San Raffaele Scientific Institute, 20132 Milan, Italy

${ }^{6}$ Department of Obstetrics and Gynecology, University of Bologna, 40138 Bologna, Italy

Correspondence should be addressed to Paolo Fiorina, paolo.fiorina@childrens.harvard.edu

Received 17 November 2011; Accepted 18 January 2012

Academic Editor: Paolo Madeddu

Copyright () 2012 Roberto Bassi et al. This is an open access article distributed under the Creative Commons Attribution License, which permits unrestricted use, distribution, and reproduction in any medium, provided the original work is properly cited.

Hyperglycaemia occurring in diabetes is responsible for accelerated arterial remodeling and atherosclerosis, affecting the macroand the microcirculatory system. Vessel injury is mainly related to deregulation of glucose homeostasis and insulin/insulinprecursors production, generation of advanced glycation end-products, reduction in nitric oxide synthesis, and oxidative and reductive stress. It occurs both at extracellular level with increased calcium and matrix proteins deposition and at intracellular level, with abnormalities of intracellular pathways and increased cell death. Peripheral arterial disease, coronary heart disease, and ischemic stroke are the main causes of morbidity/mortality in diabetic patients representing a major clinical and economic issue. Pharmacological therapies, administration of growth factors, and stem cellular strategies are the most effective approaches and will be discussed in depth in this comprehensive review covering the regenerative therapies of diabetic microangiopathy.

\section{Introduction}

Diabetes represents one of the greatest medical and socioeconomic emergencies worldwide. Approximately 17.5 million people have been diagnosed with diabetes in the USA and their number is continuously growing by 1 million per year [1]. Hyperglycaemia, occurring in type 1 (T1D) and type 2 diabetes (T2D), is responsible for a wide number of complications, with the vascular ones representing the leading cause of morbidity and mortality in diabetic patients [2]. Accelerated arterial remodeling, atherosclerosis, and endothelial cell dysfunction, affecting the macro- and the microcirculatory system, are the main evidences and lead to progressive tissue hypoperfusion and hypoxia [3]. In diabetes, multiple actors concur in causing vascular remodeling, among them metabolic factors (e.g., hyperglycaemic and oxidative stress) which are important for chemical and biological modifications of the extracellular matrix, endothelial/vascular smooth muscle cells, and mechanical factors (e.g., wall shear and circumferential stress) due to the concomitant hypertension, which cause enhanced inward remodeling, paralleled by intima/media thickening, and attenuation of vessel dilation $[4,5]$. Moreover, hyperglycaemia and advanced glycation end products (AGEs) have been shown to increase the matrix surrounding endothelial cells and vascular smooth muscle cells, increasing the deposition of proteins and the entrapment of molecules and reducing metalloproteinases activity, thus being responsible for impaired vessel dilation and wall stiffening $[6,7]$. Interestingly, the UK Prospective Diabetes Study (UKPDS) and Diabetes Control of Complications Trial (DCCT) have found microvascular disease and hyperglycaemia intrinsically related [8]. Pharmacological therapies with anti-inflammatory and anti-AGE/ROS drugs, angiogenesis inhibitors, administration of growth factors, either as recombinant proteins or via gene transfer, and stem cellular strategies are the most effective approaches and will be 
TABLE 1: Role of $\beta$-cell replacement in the treatment of diabetic microangiopathic complications divided by site of pathology. Islet and pancreas transplantation generally stabilize and in some cases improve the major diabetic complications in the long term. RAGE: advanced glycation end products receptor.

\begin{tabular}{|c|c|c|c|}
\hline Complication & Pancreas transplantation & Islet transplantation & References \\
\hline Ocular & $\begin{array}{l}\text { Does not prevent diabetic retinopathy, } \\
\text { while the reversal is still controversial }\end{array}$ & $\begin{array}{l}\text { Stabilization of retinopathy, } \\
\text { Increase in arterial and venous retinal } \\
\text { blood flow velocity }\end{array}$ & $\begin{array}{l}\text { Ramsay et al. N Engl J Med, } \\
1988 \text { [9]; Lee et al. Transplant } \\
\text { Proc, 2005 [10]; Venturini et al. } \\
\text { Transplantation } 2006 \text { [11] }\end{array}$ \\
\hline Renal & $\begin{array}{l}\text { Reduction in the thickness of the } \\
\text { glomerular and tubular basement } \\
\text { membranes, } \\
\text { Decreased urinary albumin excretion }\end{array}$ & $\begin{array}{l}\text { Retarded progression of diabetic } \\
\text { nephropathy, } \\
\text { Decreased urinary albumin excretion } \\
\text { survival of the kidney graft }\end{array}$ & $\begin{array}{l}\text { Fioretto et al. N Engl J Med, } \\
1998 \text { [12] and Lancet, } 1993 \\
\text { [13]; Fiorina et al. J Am Soc } \\
\text { Nephrol, } 2003 \text { [14] }\end{array}$ \\
\hline Neurological & $\begin{array}{l}\text { Progressive improvement of nerve } \\
\text { conduction velocity }\end{array}$ & $\begin{array}{l}\text { Positive impact on polyneuropathy, } \\
\text { Reduce nerves' RAGE expression, } \\
\text { Conservation of perineurium and vasa } \\
\text { nervorum }\end{array}$ & $\begin{array}{l}\text { Kennedy et al. N Engl J Med, } \\
1990 \text { [15]; Del Carro et al. } \\
\text { Diabetes Care, } 2007 \text { [16] }\end{array}$ \\
\hline Cardiovascular & $\begin{array}{l}\text { Positive effects on atherosclerosis } \\
\text { coronary and carotid intimal thickness } \\
\text { reduction } \\
\text { Peripheral vascular disease can worsen }\end{array}$ & $\begin{array}{l}\text { Reduction in carotid intima media } \\
\text { thickness } \\
\text { Stabilization of microangiopathy in skin } \\
\text { biopsies } \\
\text { Improved dyastolic function } \\
\text { Reduced hemostatic abnormalities }\end{array}$ & $\begin{array}{l}\text { Fiorina et al. Diabetes Care, } \\
2005 \text { [17], Del Carro et al. } \\
\text { Diabetes Care } 2007 \text { [16]; Larsen } \\
\text { et al. Diabetes Care, } 2007 \text { [18] }\end{array}$ \\
\hline
\end{tabular}

discussed in depth in this comprehensive review covering the regenerative therapies of diabetic microangiopathy.

\section{2. $\beta$-Cell Replacement}

Subcutaneous daily insulin injections improve glycometabolic control and HbA1c\% levels; however they are not able to entirely halt the occurrence of diabetic complications [13]. $\beta$-cell replacement, either pancreas or islet transplantation, is a life-saving intervention which can restore normoglycaemia [19].

2.1. Pancreas Transplantation. Despite being a procedure still affected by major risks, pancreas transplantation, when successful, leads to an immediate insulin withdrawal, as the newly transplanted pancreas is capable to secrete insulin immediately after the revascularization, normalizing $\mathrm{HbA} 1 \mathrm{c} \%$ levels in the long term (up to 10 years) [20]. Diabetic retinopathy is the most frequent diabetic complication with at least $75 \%$ of patients with T1D developing the disease by 10 years and $40 \%$ of them degenerating into blindness within 3 years [21]. Studies performed in diabetic patients receiving pancreas or kidney-pancreas transplantation have shown that the normoglycaemia achieved with these approaches do not prevent or reverse diabetic retinopathy [9] (Table 1). Conversely, Wang et al. reported regression of diabetic nephropathy at 1 year in $43 \%$ of simultaneous kidney-pancreastransplanted subjects [22]. In general, it has been shown that pancreas transplantation halts the progression of diabetic nephropathy $[13,23,24]$ (Table 1 ). Studies performed on pancreas-transplanted patients have shown that diabetic glomerular lesions affecting their own kidneys prior to transplantation were not ameliorated by 5 years of normoglycaemia, while an improvement was observed after 10 years $[12,13]$ (Table 1). Different studies have shown that neuropathy progression (and the associated vascular degeneration) can be halted by successful pancreas transplantation $[15,25,26]$. Martinenghi et al. reported that progressive amelioration of nerve conduction velocity was prominently related to the pancreas graft, given that in a cohort of kidneypancreas-transplanted patients, the failure of the pancreas, that occurred at least 2 years after successful combined transplantation, was associated with a deterioration of nerve conduction velocity back to pretransplant levels [27]. Coronary intimal thickness has been reported to regress in $40 \%$ of transplanted patients, as well as carotid atherosclerotic plaques have been seen to improve within 2 years after pancreas transplantation [28].

2.2. Islet Transplantation. Islet transplantation is a new concept $\beta$-cell replacement alternatively employed to pancreas transplantation in selected groups of patients suffering from severely poor glycaemic control and recurrent hypoglycaemic episodes, especially if associated with reduced hypoglycaemic awareness [8]. Lee et al. reported a stabilization of retinopathy in islet transplanted patients in some cases even at 1 year after transplant [10]. Venturini et al. investigated through color-Doppler-imaging the blood flow of the central retinal arteries in a group of islet-transplanted patients, before and at 1 year after transplantation, and found a significant increase in arterial and venous retinal blood flow velocities in transplanted patients compared to the control group [11] (Table 1). Islet transplantation is often performed in diabetic patients who have already experienced a kidney transplant due to end-stage renal disease; however, no unique interpretation about islet transplantation role on kidney graft function has been reached so far. Our group showed that in T1D patients islet transplantation is able to improve kidney graft survival and function, also decreasing microalbuminuria [14] (Table 1). Lee et al. studied the peripheral nerve 
function of islet transplanted patients demonstrating that $\beta$-cell replacement has a positive impact on polyneuropathy as well [10]. Accordingly, Del Carro et al. showed that islet transplantation may stabilize or even improve polyneuropathy by reducing AGE receptors (RAGEs) expression in formerly kidney-transplanted T1D patients [16] (Table 1). In the same work, skin biopsies from islet-transplanted patients showed a higher conservation degree of perineurium and vasa nervorum compared to end-stage renal disease and kidney-transplanted T1D subjects [16]. In a previous work, we similarly demonstrated that skin biopsies performed in successful islet transplanted patients, showed a stabilization of diabetic microangiopathy after 3 years of follow-up, with an increased expression of endothelial nitric oxide and von Willebrand factor, associated with a reduction of capillary basement membrane thickness and endothelial cellular swelling [17] (Table 1).

\section{Pharmacological Therapies}

3.1. Anti-Inflammatory Drugs. High glucose concentrations induce the production of the proinflammatory cytokine IL1 in human pancreatic $\beta$-cells, contributing to impaired insulin secretion and $\beta$-cell proliferation [29]. In a randomized double-blind, trial, anakinra (a recombinant human IL1 receptor antagonist) reduced HbA1c\% and IL- 6 concentration increasing C-peptide secretion in T2D patients [18]. Recent studies suggested that anti-inflammatory drugs may have an important role in diabetes therapy. The administration of salsalate (a prodrug carrying fewer side effects than aspirin) for a period of 2-4 weeks in T2D patients was able to reduce glucose blood concentrations while increasing insulin secretion [30-34]. Pentoxifylline is an anti-inflammatory methyl-xanthine derivative which is currently studied in a number of clinical trials evaluating its role in diabetic patients with nephropathy. It has been shown to significantly decrease proteinuria in both T1D and T2D patients; however given the small number of patients and the short duration of the studies, additional research is required to determine whether long-term use of pentoxifylline could be considered for the prevention or treatment of diabetic complications $[35,36]$. Finally, it is becoming more and more evident that conventional therapies for diabetes are effective in reducing inflammation and improving diabetes outcomes via indirect or pleiotropic mechanisms. In fact, lifestyle modifications promoting weight loss, caloric restriction, and physical exercise, together with metformin and statin therapy, have recently been shown to reduce high $\mathrm{C}$ reactive protein levels in T2D patients [37, 38].

3.2. PKC Inhibitors. Hyperglycaemia is a fundamental metabolic factor involved in the development of both micro- and macrovascular complications, having numerous adverse effects such as the chronic activation of protein kinase C (PKC), a family of enzymes profoundly involved in the control of multiple cellular pathways [39]. Different PKC isoforms (PKC- $\alpha,-\beta 1 / 2$, and PKC- $\delta$ ) have been shown to be associated with vascular alterations such as modifications of permeability, angiogenesis, synthesis of the extracellular matrix, cell growth/apoptosis, leukocytes migration, and cytokines production, thus leading to pathologies affecting the macrovasculature (atherosclerosis, cardiomyopathy) and the microvasculature (retinopathy, nephropathy, and neuropathy) [40]. Both preclinical and clinical studies using PKC- $\beta$ inhibitors have been carried out, obtaining encouraging results. The PKC- $\beta$ inhibitor ruboxistaurin (LY333531, RBX/Arxxant; Eli Lilly and Company, Indianapolis, IN) was employed in murine models of diabetes with virtually no effect on $\mathrm{HbA1c} \%$, blood glucose level, or blood pressure, however leading to normalization of glomerular filtration rate (GFR), urinary albumin, and TGF- $\beta 1$ excretion and also reducing the glomerular and mesangial extracellular matrix $[41,42]$. A multicenter pilot study evaluated the effect of LY333531 (32 mg/day) in T2D patients affected by diabetic nephropathy in addition to their current therapy with angiotensin-converting enzyme inhibitors and angiotensin receptor blockers, showing a $25 \%$ reduction in urinary albumin creatinine ratio (ACR) after 1 year and a conservation of the estimated GFR level [43]. The PKC- $\beta$ inhibitor diabetic retinopathy study (PKC-DRS) reported a lower incidence of visual loss, need for laser treatment, and macular oedema progression in T1D and T2D patients treated with $32 \mathrm{mg} /$ day LY333531 for 36-46 months [44, 45]. Inhibition of PKC- $\beta$ through LY333531 is also beneficial to patients with symptomatic diabetic neuropathy, improving sensory symptoms and vibration sensation $[46,47]$. A phase II multinational pilot study assessed the effect of LY333531 (32 or $64 \mathrm{mg} /$ day for 1 year) in patients with diabetic neuropathy demonstrating a significant reduction of total symptoms and improvement at the vibration detection threshold [48]. Treatment with LY333531 (32 mg/day for 7 days) has been shown to prevent endothelium-dependent vasodilation abnormalities induced by hyperglycaemia as well [49].

3.3. AGEs and Oxidative Stress Strategies. Diabetes is characterized by abnormalities of mitochondrial ROS production that generate an increased oxidative stress in endothelial cells thus causing the development of diabetes complications [50]. In physiologic ageing AGEs can target proteins forming irreversible complexes that become resistant to proteolytic degradation; however, in the diabetic state the process results accelerated [51]. Aminoguanidine, scavenging intermediates in the glycation catalytic process, inhibits the formation of AGEs slowing the progression of diabetic nephropathy [52]; however the first clinical study performed in T1D patients with nephropathy and retinopathy, beside recording a consistent reduction of proteinuria, reported retinopathy worsening in some treated patients compared to placebo [53]. Vitamins of the B group represent another approach for the reduction of AGEs-related complications [54]. Preclinical studies revealed that pyridoxamine is effective in preserving kidney function in T1D and T2D murine models [54]. Consistently phase II clinical trials in proteinuric T1D and T2D patients showed a significant decrease in serum creatinine level, albumin, and TGF- $\beta$ urinary excretion. An ongoing phase IIb study (http://clinicaltrials.gov/, NCT00734253) is 
evaluating the safety and efficacy of pyridoxine in nephropathic T2D patients. Finally, another clinical trial (http:// clinicaltrials.gov/, NCT00565318) is now assessing the effect of benfotiamine, a lipophilic analogue of thiamine $\left(B_{1}\right.$ vitamin), on urinary albumin and $\beta_{2}$-microglobulin excretion in T2D patients. Another class of therapeutic agents useful in reducing AGEs accumulation is advanced glycation crosslink breakers. Recently TRC4186 has been shown to decrease albuminuria and improve kidney function in diabetic mice with progressive cardiac and kidney failure, but 2-week treatment with ALT-711 (alagebrium), a novel AGE breaker compound had no effects on motor/nociceptive nerve dysfunction and vascular stiffness in diabetic mice after 8 weeks of diabetes $[55,56]$. A clinical trial evaluating the effect of alagebrium (200 mg twice daily) on diabetic nephropathy (http://clinicaltrials.gov/, NCT00557518) reported a decrease in arterial pulse pressure and an increase in endothelial function and artery compliance $[57,58]$.

3.4. Inhibitors of Angiogenesis. Vascular endothelial growth factor (VEGF) is overproduced in the diabetic retina in response to capillary loss and/or microaneurysm formation; thus inhibition of VEGF activity may play a pivotal role in the prevention of diabetes-related retinopathy [59]. Currently, there are three main anti-VEGF agents under investigation: pegaptanib sodium, a pegylated RNA aptamer that binds $\mathrm{VEGF}_{165}$ and the longer VEGF isoforms (Macugen; Eyetech Pharmaceuticals Inc, New York, and Pfizer Inc, NY); ranibizumab, a recombinant humanized monoclonal antibody specific for all human VEFG isoforms (Lucentis; Genentech Inc, South San Francisco, CA), and bevacizumab, another full-length humanized monoclonal antibody against all isoforms of human VEGF (Avastin; Genentech, South San Francisco, CA) [60]. VEGF has a role in the pathogenesis of diabetic nephropathy as well. SU5416 by selectively blocking all VEGF receptors at the level of the tyrosine kinase has been reported to ameliorate albuminuria in an experimental model of diabetic nephropathy [61]. In preclinical studies ruboxistaurin attenuated the effect of VEGF and so the progression of diabetic nephropathy [62].

\section{Cellular Therapies}

Stem cells have the unique ability to potentially originate any organ or tissue, being undifferentiated and capable of selfrenewal [63]. Stem cells can be obtained from embryos, umbilical cord blood, and adult tissues (as bone marrow or adipose tissue) [63].

4.1. Cord Blood Stem Cells. Cord blood stem cells (CB-SCs) are a heterogeneous population composed of (i) very small embryonic-like stem cells, (ii) mesenchymal stem cells (MSCs), (iii) hematopoietic stem cells, and (iv) endothelial progenitor cells (EPCs) [63]. CB-SCs are easily collectable from 60-80 cc of umbilical cord blood and exhibit common features like the presence of long and highly preserved telomeres, the ability to form colonies when cultured in vivo, and a virtually absent oncogenic potential $[63,64]$. An experimental study performed by Naruse et al. highlighted the therapeutic role for ex vivo expanded CB-EPCs in the treatment of diabetic neuropathy, showing that hind limb EPCs intramuscular injection into streptozotocin- (STZ-) induced diabetic rats improved muscles microvascular net, sciatic nerve conduction velocity, and endoneurial nutritive blood flow [65] (Table 2). Additionally, a clinical trial evaluating safety and efficacy of allogeneic CB-MSCs injections into pathologic lower limbs of T2D patients affected by peripheral arterial disease is currently ongoing at the Stem Cell Research Center at Qingdao University, (http://clinicaltrials .gov/, NCT01216865).

4.2. Mesenchymal Stem Cells. Among stem cells, great clinical interest is reserved to MSCs. Beside their potential to differentiate $[66,67]$, MSCs are characterized by strong hypoimmunogenic features, such as low expression of MHC-Irelated antigens and absence of MHC-II antigens [68], making these cells immune privileged [69-77] (e.g., MSCs neither induce $\mathrm{CD}^{+}$activation nor are subjected to cell lysis induced by cytotoxic lymphocytes [78]). Moreover, MSCs are able to exert anti-inflammatory actions, for instance, by decreasing the secretion of TNF- $\alpha$ by dendritic cells $[76,77]$. In a murine model of diabetic cardiomiopathy, Zhang et al. evaluated the ability of intravenous administration of BMMSCs to either promote angiogenesis and mitigate ventricular remodeling, reporting an increased number of myocardial arterioles, an improvement of cardiac functionality, and a decrease of metalloproteinases activity, with a consequent smoothing of heart remodeling [79] (Table 2). Additionally, $\mathrm{Wu}$ et al. showed that allogeneic transplantation of BMMSCs significantly promoted wound healing in diabetic $d b / d b$ mice by accelerating reepithelialization and reconstituting capillary network density [80] (Table 2). Finally, Yang et al. showed that adipose-derived MSCs infusion in an STZ-induced murine model of diabetic retinopathy reduced blood glucose level and blood retinal barrier damage [81] (Table 2).

4.3. Endothelial Progenitor Cells. EPCs are circulating cells originating from several tissues such as bone marrow, peripheral blood, and cord blood, which are able to generate mature endothelial cells and vascular structures [82]. Thanks to their involvement in angiogenic and vasculogenic processes [82-86], EPCs represent an additional powerful tool for the treatment of diabetic microvascular complications. Interestingly, Barcelos et al. showed that human fetal aorta $\mathrm{CD}_{133^{+}}$progenitor cells, when transplanted into a murine model of diabetic wound, are either able to promote angiogenesis and to release VEGF-A in a high-frequency fashion [87]. Fiorina et al. demonstrated that the mobilization of endogenous BM-EPCs to the site of wound in a mouse model of diabetic wound healing is improved by the targeting of CXCR4/CXCL12 axis through a CXCR4 antagonist [88]. A currently ongoing phase I clinical trial is evaluating the efficacy and safety of the administration of AMD3100 (Plerixafor) and rhPDGF-BB (Becaplermin), two novel agents able 
TABLE 2: Overview of the experimental studies describing the role of stem cells in diabetic microangiopathy treatment and prevention. AD: adipose derived; BM: bone marrow; CB: cord blood; EPCs: endothelial progenitor cells; MSCs: mesenchymal stem cells; BRB: blood retinal barrier.

\begin{tabular}{|c|c|c|c|}
\hline Complication & Cells & Outcomes & References \\
\hline Neurological & CB-EPCs & $\begin{array}{l}\text { Increased number of microvessels, } \\
\text { Improved sciatic motor nerve conduction velocity, } \\
\text { Increase of sciatic endoneurial nutritive blood flow }\end{array}$ & Naruse et al. Diabetes, 2005 [65] \\
\hline Cardiovascular & BM-MSCs & $\begin{array}{l}\text { Enhanced number of myocardial arterioles, } \\
\text { Increase in fractional shortening, } \\
\text { Mitigation of heart remodeling. }\end{array}$ & $\begin{array}{l}\text { Zhang et al. Exp Clin Endocrinol } \\
\text { Diabetes, } 2008 \text { [79] }\end{array}$ \\
\hline Wound Healing & BM-MSCs & $\begin{array}{l}\text { Acceleration of wounds healing, } \\
\text { Increase in capillary density. }\end{array}$ & Wu et al. Stem cells, 2007 [80] \\
\hline Ocular & AD-MSCs & Repair of BRB damages & $\begin{array}{l}\text { Yang et al. Graefes Arch Clin Exp } \\
\text { Ophthalmol, } 2010 \text { [81] }\end{array}$ \\
\hline Wound Healing & BM-EPCs & Promotion of neovascularization. & Asai et al. Circulation, 2006 [89] \\
\hline Neurological & BM-EPCs & $\begin{array}{l}\text { Restoring of nerve conduction velocity, } \\
\text { Increased blood flow in sciatic nerve, } \\
\text { Increased nerves capillary density. }\end{array}$ & Jeong et al. Circulation, 2009 [90] \\
\hline
\end{tabular}

to mobilize endogenous BM-EPCs, for the treatment of peri-pheral arterial disease in T2D patients, (http://clinicaltrials.gov/, NCT01353937). Recently, Asai et al. demonstrated that Sonic Hedgehog (SHh, a protein that stimulates BM-EPCs proliferation/migration and VEGF production, promoting the neovascularization of ischemic tissues) was responsible for wound healing acceleration in $d b / d b$ mice by enhancing angiogenesis and recruiting BM-EPCs into the wound [89] (Table 2). Jeong et al. reported that hind limb BM-EPCs infusion was able to reverse diabetic neuropathy in STZ-induced diabetic mice, improving sciatic nerve conduction velocity and blood flow, compared to saline treated controls [90] (Table 2). Finally, transplanted BM-EPCs exhibited homing attitudes to the sciatic nerve and its vasa nervorum, also reporting a paracrine activity realized through the release of either angiogenic and neurotrophic factors [90] (Table 2).

\section{Gene Therapy}

Growth factors administration by gene transfer is a promising approach for the treatment of diabetic microangiopathy, promoting endothelial cell proliferation, migration, and blood vessel formation.

5.1. Vascular Endothelial Growth Factor. VEGF is an endothelial-specific growth factor that promotes endothelial cells proliferation, differentiation, and survival, mediates endothelium-dependent vasodilation, induces microvascular hyperpermeability, and participates in interstitial matrix remodeling [91]. Notably, at low concentration VEGFs are mostly vasculoprotective, at high concentration have angiogenic effects, whereas at sustained high dose cause pathological angiogenesis [91]. VEGF-A, particularly its 165 isoform, plays a major role in vascular biology and is the first candidate for therapeutic applications in vivo $[92,93]$. Isner et al. first demonstrated the tolerability of plasmid injection transferring a human $\mathrm{VEGF}_{165}$ encoding plasmid ( $\mathrm{ph}$ ) in patients with peripheral arterial disease [94, 95]. The safety and beneficial results of phVEGF ${ }_{165}$ were reported as well by Shyu et al. in patients with critical limb ischemia (CLI) [96]. Similarly, intramuscular phVEGF 165 was tested in ischemic neuropathic patients [97]; however, no relevant biologic effects were obtained due to the partial inefficiency of VEGF gene transfer [98]. Conversely, a phase I study demonstrated the major efficiency of adenoviral (Ad) vector in $\mathrm{VEGF}_{121}$ transfer in severe vascular disease patients, showing an increase of lower-extremity flow reserve in response to acetylcholine [99]. Less optimistic outcomes were shown in other studies where Ad.VEGF 121 administration in patients with intermittent claudication was not associated with an improvement in exercise performance and quality of life, and similarly, treatment with Ad.VEGF 165 did not reduce the rate of amputation events [100] (Table 3).

5.2. Fibroblast Growth Factors. Fibroblast growth factor (FGFs) is a large family of proteins capable of modulating the proliferation and migration of endothelial cells, fibroblasts, and smooth muscle cells [101]. FGF-1 is a potent mitogen for vascular cells and induces the formation of mature blood vessels in vivo. In 2007, Sanofi-Aventis started a promising trial (currently ongoing) based on the gene transfer of FGF-1 plasmid DNA in patients with CLI, known as TAMARIS (Therapeutic Angiogenesis for the Management of Arteriopathy in a Randomized International Study) [102], aiming at evaluating the efficacy and safety of intramuscular administration of NV1FGF in CLI patients, a plasmid-based gene delivery system for the local expression of FGF-1 $[103,104]$ (Table 3). After 1 year of follow-up, the primary endpoint of major amputations or death occurrence did not differ between the treated and the placebo arm [105]. FGF-4 has been shown to stimulate endothelial cells proliferation, migration, and neovascularization in vivo by upregulating endogenous VEGF-A expression [106]. Indeed, a currently ongoing clinical trial is evaluating the therapeutical potential of VEGF$\mathrm{A}_{165}$ /basicFGF delivery in the myocardium of refractory 
TABLE 3: Role of gene transfer in the treatment of diabetic microangiopathy. Gene transfer promotes endothelial cell proliferation, migration, and blood vessel formation. VEGF: vascular endothelial growth factor; FGF: fibroblast growth factor; HGF: hepatocyte growth factor; HIF$1 \alpha$ : hypoxia inducible factor- $1 \alpha$.

\begin{tabular}{|c|c|c|c|c|c|}
\hline & Study & Year & Identifier & Site & Status/recruited pts \\
\hline \multirow[t]{2}{*}{ VEGF } & $\begin{array}{l}\text { Vegf gene transfer for critical limb } \\
\text { ischemia }\end{array}$ & 2010 & NCT00056290 & $\begin{array}{l}\text { Steward St. Elizabeth's } \\
\text { Medical Center of } \\
\text { Boston }\end{array}$ & Completed \\
\hline & $\begin{array}{l}\text { VEGF gene transfer for diabetic } \\
\text { neuropathy }\end{array}$ & 2010 & NCT00056290 & $\begin{array}{l}\text { Steward St. Elizabeth's } \\
\text { Medical Center of } \\
\text { Boston }\end{array}$ & Completed \\
\hline \multirow{3}{*}{ FGF } & $\begin{array}{l}\text { Angiogenesis using VEGF-A165/bFGF } \\
\text { plasmid delivered percutaneously in } \\
\text { no-option CAD patients; a controlled } \\
\text { trial (VIF-CAD) }\end{array}$ & 2009 & NCT00620217 & $\begin{array}{l}\text { Institute of Cardiology, } \\
\text { Warsaw, Poland }\end{array}$ & Completed \\
\hline & $\begin{array}{l}\text { Efficacy and safety study of NV1FGF in } \\
\text { patients with severe peripheral artery } \\
\text { occlusive disease (TALISMAN202) }\end{array}$ & 2010 & NCT00798005 & Sanofi-Aventis & Completed \\
\hline & $\begin{array}{l}\text { Efficacy and safety of } \\
\text { XRP0038/NV1FGF in critical limb } \\
\text { ischemia patients with skin lesions } \\
\text { (TAMARIS) }\end{array}$ & 2010 & NCT00566657 & Sanofi-Aventis & $\begin{array}{l}\text { This study is ongoing, but not } \\
\text { recruiting participants }\end{array}$ \\
\hline HGF & $\begin{array}{l}\text { Study of hepatocyte growth factor } \\
\text { (HGF) via plasmid vector to improve } \\
\text { perfusion in critical limb ischemia } \\
\text { patients with peripheral ischemic ulcers }\end{array}$ & 2011 & NCT00189540 & AnGes & This study has been completed \\
\hline HIF & $\begin{array}{l}\text { Safety and efficacy study of } \\
\text { Ad } 2 / \text { Hypoxia inducible factor- } 1 \alpha \\
\text { (HIF- } 1 \alpha \text { )/VP16 gene transfer in patients } \\
\text { with intermittent claudication (WALK) }\end{array}$ & 2010 & NCT00117650 & Genzyme & This study has been completed \\
\hline
\end{tabular}

coronary artery disease patients [102]. So far, most efforts have concentrated on a single gene delivery therapy; however as multiple proteins are involved in the angiogenic process, efficiently delivering more than one gene might be a valuable approach [106].

5.3. Hepatocyte Growth Factor. Hepatocyte growth factor (HGF) is a large protein first identified as a potent hepatocyte mitogen and only lately discovered to stimulate endothelial cells growth [107]. Preclinical studies have shown that the delivery of HGF as a recombinant protein or naked plasmid induces therapeutic angiogenesis in rat or rabbit peripheral arterial disease models [108, 109]. Similarly, muscular injection of naked human HGF plasmid resulted in increased blood flow in the same models [109]. Following these preclinical results, the safety and efficacy of HGF plasmid administration was investigated in patients with CLI, evaluating limb tissue perfusion by transcutaneous oxygen tension measurement and reporting higher values of oxygen tension at 6 months as compared to controls [110] (Table 3).

5.4. Hypoxia-Inducible Factor-1. Hypoxia-inducible factor-1 (HIF-1) is a mesenchyme-derived pleiotropic transcriptional activator that acts as a regulator of oxygen homeostasis [111]. HIF-1 is a heterodimer composed of a constitutively expressed HIF- $1 \beta$ subunit and $\mathrm{O}_{2}$-regulated HIF- $1 \alpha$ subunit, with the latter increasing at low oxygen levels [111]. The complex of HIF- $1 \beta / \alpha$ regulates the expression of many genes, including VEGF [111]. The injection of plasmid DNA encoding HIF- $1 \alpha$ stimulates the recovery of blood flow in hind limb ischemia animal models $[112,113]$. Similarly, intramuscular injection of adenovirus encoding functional HIF- $1 \alpha$ in a murine model of hind limb ischemia increased the recovery of limb perfusion [113]. Finally, intramuscular injection of escalating dose of adenoviral HIF- $1 \alpha$-VP16 in patients with CLI has shown tolerability and safety [114] (Table 3).

5.5. Nerve Growth Factor. Recently, nerve growth factor (NGF) has been discovered to have cardiovascular protective roles and angiogenetic capabilities [115]. For these reasons, it is becoming particularly appealing for the treatment of diabetes vascular complications. Emanueli et al. strikingly introduced the concept of neurotrophins, particularly NGF, as autocrine proangiogenetic factors, promoting the growth of new capillaries and accelerating blood flow recovery in ischemic muscles of a mouse model of limb ischemia [116]. In fact, NGF seems to induce angiogenesis by increasing the expression level of VEGF-A and VEGF receptors [116, 117] and also by promoting NO production and metalloproteinases upregulation $[116,118]$. Accordingly, Meloni et al. translated these findings into a gene therapy approach for the prevention of diabetic cardiomyopathy in a murine model 
of diabetes [119]. After 2 weeks of diabetes, mice were treated with NGF gene transfer via adenoassociated viral vectors [119]. Treated mice were found to be protected from myocardial microvascular rarefaction, hypoperfusion, increased deposition of interstitial fibrosis, and increased apoptosis of endothelial cells and cardiomyocytes [119].

5.6. Kallikreins. Kallikreins can be divided in tissue and plasma kallikreins differing in molecular weight, substrate specificities, and type of kinin released. Tissue kallikrein is a glycoprotein that stimulates cells to release autacoids such as nitric oxide and prostaglandins [120]. Circulating tissue kallikrein levels are increased in patients with peripheral obstructive vascular disease and in skeletal muscle after the induction of hind limb ischemia [121]. The angiogenic potential of tissue kallikrein in peripheral ischemia has been established in preclinical models using a gene-transfer approach [122]. Replication-defective adenoviral vector containing the human tissue kallikrein gene was injected into the adductor skeletal muscle of mice submitted to unilateral limb ischemia [123]. The successful transduction of the transgene resulted in ameliorated angiogenic response and haemodynamic recovery [123]. Emanueli et al. have also documented that human tissue kallikrein is able to prevent diabetic microangiopathy in STZ-induced diabetic murine models [124].

\section{Conclusions}

Multidisciplinary management of diabetes is of outstanding importance for the treatment and the prevention of diabetic complications, being helpful in reducing social costs and the detriment to the patient; however newer therapeutic approaches are needed. Novel mechanistic insights in the pathogenesis of endothelial dysfunction are rapidly being translated into new therapeutic opportunities; stem cells are expected to become promising therapeutic agents for diabetic patients due to their immunomodulatory characteristics, self-renewal, and differentiation ability; many clinical trials are demonstrating gene therapy as a valuable option to treat peripheral arterial disease. Nonetheless, gene therapy together with the cellular one is still waiting for randomized placebo-controlled double-blind, large-scale, clinical trials, ultimately defining their clinical role. Despite only short- and midterm follow-up data are available and long-term safety and efficacy end-points are required, some of these new strategies are close to become established therapeutic options, and some others hold in them the potential to halt diabetic complications.

\section{Acknowledgments}

P. Fiorina is the recipient of JDRF-Career Development Award, ASN Career Development Award, ADA mentorbased fellowship, and MIUR Grant ("Staminali" RF-FSR2008-1213704) and a TRP (Translational Research Program) Grant. R. Bassi is supported by an ADA mentor-based fellowship to P. Fiorina.

\section{References}

[1] H. King, R. E. Aubert, and W. H. Herman, "Global burden of diabetes, 1995-2025: prevalence, numerical estimates, and projections," Diabetes Care, vol. 21, no. 9, pp. 1414-1431, 1998.

[2] N. Chaturvedi, "The burden of diabetes and its complications: trends and implications for intervention," Diabetes Research and Clinical Practice, vol. 76, no. 3, pp. S3-S12, 2007.

[3] A. R. Pries, B. Reglin, and T. W. Secomb, "Remodeling of blood vessels: responses of diameter and wall thickness to hemodynamic and metabolic stimuli," Hypertension, vol. 46, no. 4 , pp. $725-731,2005$.

[4] A. M. Heagerty, C. Aalkjaer, S. J. Bund, N. Korsgaard, and M. J. Mulvany, "Small artery structure in hypertension: dual processes of remodeling and growth," Hypertension, vol. 21, no. 4, pp. 391-397, 1993.

[5] D. M. Nathan, P. A. Cleary, J. Y. C. Backlund et al., "Intensive diabetes treatment and cardiovascular disease in patients with type 1 diabetes," New England Journal of Medicine, vol. 353, no. 25, pp. 2643-2653, 2005.

[6] A. Goldin, J. A. Beckman, A. M. Schmidt, and M. A. Creager, "Advanced glycation end products: sparking the development of diabetic vascular injury," Circulation, vol. 114, no. 6, pp. 597-605, 2006.

[7] Z. S. Galis and J. J. Khatri, "Matrix metalloproteinases in vascular remodeling and atherogenesis: the good, the bad, and the ugly," Circulation Research, vol. 90, no. 3, pp. 251-262, 2002.

[8] H. Shamoon, H. Duffy, N. Fleischer et al., "The effect of intensive treatment of diabetes on the development and progression of long-term complications in insulin-dependent diabetes mellitus," New England Journal of Medicine, vol. 329, no. 14, pp. 977-986, 1993.

[9] R. C. Ramsay, F. C. Goetz, D. E. R. Sutherland et al., "Progression of diabetic retinopathy after pancreas transplantation for insulin-dependent diabetes mellitus," New England Journal of Medicine, vol. 318, no. 4, pp. 208-214, 1988.

[10] T. C. Lee, N. R. Barshes, C. A. O’Mahony et al., "The effect of pancreatic islet transplantation on progression of diabetic retinopathy and neuropathy," Transplantation Proceedings, vol. 37, no. 5, pp. 2263-2265, 2005.

[11] M. Venturini, P. Fiorina, P. Maffi et al., "Early increase of retinal arterial and venous blood flow velocities at color doppler imaging in brittle type 1 diabetes after islet transplant alone," Transplantation, vol. 81, no. 9, pp. 1274-1277, 2006.

[12] P. Fioretto, M. W. Steffes, D. E. R. Sutherland, F. C. Goetz, and M. Mauer, "Reversal of lesions of diabetic nephropathy after pancreas transplantation," New England Journal of Medicine, vol. 339, no. 2, pp. 69-75, 1998.

[13] P. Fioretto, S. M. Mauer, R. W. Bilous, F. C. Goetz, D. E. R. Sutherland, and M. W. Steffes, "Effects of pancreas transplantation on glomerular structure in insulin-dependent diabetic patients with their own kidneys," The Lancet, vol. 342, no. 8881, pp. 1193-1196, 1993.

[14] P. Fiorina, F. Folli, G. Zerbini et al., "Islet transplantation is associated with improvement of renal function among uremic patients with type I diabetes mellitus and kidney transplants," Journal of the American Society of Nephrology, vol. 14, no. 8, pp. 2150-2158, 2003.

[15] W. R. Kennedy, X. Navarro, F. C. Goetz, D. E. R. Sutherland, and J. S. Najarian, "Effects of pancreatic transplantation on diabetic neuropathy," New England Journal of Medicine, vol. 322, no. 15, pp. 1031-1037, 1990. 
[16] U. Del Carro, P. Fiorina, S. Amadio et al., "Evaluation of polyneuropathy markers in type 1 diabetic kidney transplant patients and effects of islet transplantation: neurophysiological and skin biopsy longitudinal analysis," Diabetes Care, vol. 30, no. 12, pp. 3063-3069, 2007.

[17] P. Fiorina, C. Gremizzi, P. Maffi et al., "Islet transplantation is associated with an improvement of cardiovascular function in type 1 diabetic kidney transplant patients," Diabetes Care, vol. 28, no. 6, pp. 1358-1365, 2005.

[18] C. M. Larsen, M. Faulenbach, A. Vaag et al., "Interleukin-1receptor antagonist in type 2 diabetes mellitus," New England Journal of Medicine, vol. 356, no. 15, pp. 1517-1526, 2007.

[19] R. P. Robertson, "Islet transplantation as a treatment for diabetes-a work in progress," New England Journal of Medicine, vol. 350, no. 7, pp. 694-705, 2004.

[20] R. P. Robertson, D. E. R. Sutherland, D. M. Kendall, A. U. Teuscher, R. W. G. Gruessner, and A. Gruessner, "Metabolic characterization of long-term successful pancreas transplants in type I diabetes," Journal of Investigative Medicine, vol. 44, no. 9, pp. 549-555, 1996.

[21] N. Cheung, P. Mitchell, and T. Y. Wong, "Diabetic retinopathy," The Lancet, vol. 376, no. 9735, pp. 124-136, 2010.

[22] Q. Wang, R. Klein, S. E. Moss et al., "The influence of combined kidney-pancreas transplantation on the progression of diabetic retinopathy: a case series," Ophthalmology, vol. 101, no. 6, pp. 1071-1076, 1994.

[23] E. La Rocca, C. Gobbi, D. Ciurlino, V. Di Carlo, G. Pozza, and A. Secchi, "Improvement of glucose/insulin metabolism reduces hypertension in insulin-dependent diabetes melitis recipients of kidney-pancreas transplantation," Transplantation, vol. 65, no. 3, pp. 390-393, 1998.

[24] P. Fioretto, D. E. R. Sutherland, B. Najafian, and M. Mauer, "Remodeling of renal interstitial and tubular lesions in pancreas transplant recipients," Kidney International, vol. 69, no. 5, pp. 907-912, 2006.

[25] X. Navarro, W. R. Kennedy, R. B. Lowenson, and D. E. R. Sutherland, "Influence of pancreas transplantation on cardiorespiratory reflexes, nerve conduction, and mortality in diabetes mellitus," Diabetes, vol. 39, no. 7, pp. 802-806, 1990.

[26] G. Solders, R. Gunnarsson, A. Persson, H. Wilczek, G. Tyden, and C. G. Groth, "Effects of combined pancreatic and renal transplantation on diabetic neuropathy: a two-year followup study," The Lancet, vol. 2, no. 8570, pp. 1232-1235, 1987.

[27] S. Martinenghi, G. Comi, G. Galardi, V. Di Carlo, G. Pozza, and A. Secchi, "Amelioration of nerve conduction velocity following simultaneous kidney/pancreas transplantation is due to the glycaemic control provided by the pancreas," Diabetologia, vol. 40, no. 9, pp. 1110-1112, 1997.

[28] J. W. Jukema, Y. F. C. Smets, J. W. Van Der Pijl et al., "Impact of simultaneous pancreas and kidney transplantation on progression of coronary atherosclerosis in patients with endstage renal failure due to type 1 diabetes," Diabetes Care, vol. 25, no. 5, pp. 906-911, 2002.

[29] T. Mandrup-Poulsen, L. Pickersgill, and M. Y. Donath, "Blockade of interleukin 1 in type 1 diabetes mellitus," Nature Reviews Endocrinology, vol. 6, no. 3, pp. 158-166, 2010.

[30] A. B. Goldfine, R. Silver, W. Aldhahi et al., "Use of salsalate to target inflammation in the treatment of insulin resistance and type 2 diabetes," Clinical and Translational Science, vol. 1, no. 1, pp. 36-43, 2008.

[31] A. Fleischman, S. E. Shoelson, R. Bernier, and A. B. Goldfine, "Salsalate improves glycemia and inflammatory parameters in obese young adults," Diabetes Care, vol. 31, no. 2, pp. 289294, 2008.
[32] J.-M. Fernández-Real, A. López-Bermejo, A.-B. Ropero et al., "Salicylates increase insulin secretion in healthy obese subjects," Journal of Clinical Endocrinology and Metabolism, vol. 93, no. 7, pp. 2523-2530, 2008.

[33] M. Chen and R. P. Robertson, "Restoration of the acute insulin response by sodium salicylate. A glucose dose-related phenomenon," Diabetes, vol. 27, no. 7, pp. 750-756, 1978.

[34] A. B. Goldfine, V. Fonseca, K. A. Jablonski, L. Pyle, M. A. Staten, and S. E. Shoelson, "The effects of salsalate on glycemic control in patients with type 2 diabetes: a randomized trial," Annals of Internal Medicine, vol. 152, no. 6, pp. 346$357,2010$.

[35] J. F. Navarro, C. Mora, A. Rivero et al., "Urinary protein excretion and serum tumor necrosis factor in diabetic patients with advanced renal failure: effects of pentoxifylline administration," American Journal of Kidney Diseases, vol. 33, no. 3, pp. 458-463, 1999.

[36] M. Rodríguez-Morán and F. Guerrero-Romero, "Pentoxifylline is as effective as captopril in the reduction of microalbuminuria in non-hypertensive type 2 diabetic patients-a randomized, equivalent trial," Clinical Nephrology, vol. 64, no. 2, pp. 91-97, 2005.

[37] S. Haffner, M. Temprosa, J. Crandall et al., "Intensive lifestyle intervention or metformin on inflammation and coagulation in participants with impaired glucose tolerance," Diabetes, vol. 54, pp. 1566-1572, 2005.

[38] E. M. Balk, J. Lau, L. C. Goudas et al., "Effects of statins on nonlipid serum markers associated with cardiovascular sisease: a systematic review," Annals of Internal Medicine, vol. 139, no. 8, pp. 670-682, 2003.

[39] D. Koya and G. L. King, "Protein kinase C activation and the development of diabetic complications," Diabetes, vol. 47, no. 6, pp. 859-866, 1998.

[40] P. Geraldes and G. L. King, "Activation of protein kinase C isoforms and its impact on diabetic complications," Circulation Research, vol. 106, no. 8, pp. 1319-1331, 2010.

[41] D. J. Kelly, Y. Zhang, C. Hepper et al., "Protein kinase C $\beta$ inhibition attenuates the progression of experimental diabetic nephropathy in the presence of continued hypertension," Diabetes, vol. 52, no. 2, pp. 512-518, 2003.

[42] H. Ishii, M. R. Jirousek, D. Koya et al., "Amelioration of vascular dysfunctions in diabetic rats by an oral PKC $\beta$ inhibitor," Science, vol. 272, no. 5262, pp. 728-731, 1996.

[43] K. R. Tuttle, G. L. Bakris, R. D. Toto, J. B. McGill, K. Hu, and P. W. Anderson, "The effect of ruboxistaurin on nephropathy in type 2 diabetes," Diabetes Care, vol. 28, no. 11, pp. 26862690, 2005.

[44] L. P. Aiello, "The effect of ruboxistaurin on visual loss in patients with moderately severe to very severe nonproliferative diabetic retinopathy: initial results of the protein kinase $\mathrm{C} \beta$ inhibitor diabetic retinopathy study (PKC-DRS) multicenter randomized clinical trial," Diabetes, vol. 54, no. 7, pp. 21882197, 2005.

[45] L. P. Aiello, M. D. Davis, A. Girach et al., "Effect of ruboxistaurin on visual loss in patients with diabetic retinopathy," Ophthalmology, vol. 113, pp. 2221-2230, 2006.

[46] A. I. Vinik, V. Bril, P. Kempler et al., "Treatment of symptomatic diabetic peripheral neuropathy with the protein kinase $C \beta$-inhibitor ruboxistaurin mesylate during a 1-year, randomized, placebo-controlled, double-blind clinical trial," Clinical Therapeutics, vol. 27, no. 8, pp. 1164-1180, 2005.

[47] A. I. Vinik, V. Bril, W. J. Litchy, K. L. Price, and E. J. Bastyr, "Sural sensory action potential identifies diabetic peripheral 
neuropathy response to therapy," Muscle and Nerve, vol. 32, no. 5, pp. 619-625, 2005.

[48] C. M. Casellini, P. M. Barlow, A. L. Rice et al., "A 6-month, randomized, double-masked, placebo-controlled study evaluating the effects of the protein kinase C- $\beta$ inhibitor ruboxistaurin on skin microvascular blood flow and other measures of diabetic peripheral neuropathy," Diabetes Care, vol. 30, no. 4, pp. 896-902, 2007.

[49] J. A. Beckman, A. B. Goldfine, M. B. Gordon, L. A. Garrett, and M. A. Creager, "Inhibition of protein kinase $\mathrm{C} \beta$ prevents impaired endothelium-dependent vasodilation caused by hyperglycemia in humans," Circulation Research, vol. 90, no. 1, pp. 107-111, 2002.

[50] F. Giacco and M. Brownlee, "Oxidative stress and diabetic complications," Circulation Research, vol. 107, no. 9, pp. 1058-1070, 2010.

[51] M. C. Thomas, J. W. Baynes, S. R. Thorpe, and M. E. Cooper, "The role of AGEs and AGE inhibitors in diabetic cardiovascular disease," Current Drug Targets, vol. 6, no. 4, pp. 453474, 2005.

[52] T. Soulis-Liparota, M. Cooper, D. Papazoglou, B. Clarke, and G. Jerums, "Retardation by aminoguanidine of development of albuminuria, mesangial expansion, and tissue fluorescence in streptozocin-induced diabetic rat," Diabetes, vol. 40, no. 10, pp. 1328-1334, 1991.

[53] R. G. Tilton, K. Chang, K. S. Hasan et al., "Prevention of diabetic vascular dysfunction by guanidines: inhibition of nitric oxide synthase versus advanced glycation end-product formation," Diabetes, vol. 42, no. 2, pp. 221-232, 1993.

[54] T. P. Degenhardt, N. L. Alderson, D. D. Arrington et al., "Pyridoxamine inhibits early renal disease and dyslipidemia in the streptozotocin-diabetic rat," Kidney International, vol. 61, no. 3, pp. 939-950, 2002.

[55] D. Joshi, R. Gupta, A. Dubey et al., "TRC4186, a novel AGEbreaker, improves diabetic cardiomyopathy and nephropathy in Ob-ZSF1 model of type 2 diabetes," Journal of Cardiovascular Pharmacology, vol. 54, no. 1, pp. 72-81, 2009.

[56] C. Demiot, M. Tartas, B. Fromy, P. Abraham, J. L. Saumet, and D. Sigaudo-Roussel, "Aldose reductase pathway inhibition improved vascular and C-fiber functions, allowing for pressure-induced vasodilation restoration during severe diabetic neuropathy," Diabetes, vol. 55, no. 5, pp. 1478-1483, 2006.

[57] S. J. Zieman, V. Melenovsky, L. Clattenburg et al., "Advanced glycation endproduct crosslink breaker (alagebrium) improves endothelial function in patients with isolated systolic hypertension," Journal of Hypertension, vol. 25, no. 3, pp. 577-583, 2007.

[58] D. A. Kass, E. P. Shapiro, M. Kawaguchi et al., "Improved arterial compliance by a novel advanced glycation endproduct crosslink breaker," Circulation, vol. 104, no. 13, pp. 1464-1470, 2001.

[59] G. M. Comer and T. A. Ciulla, "Pharmacotherapy for diabetic retinopathy," Current Opinion in Ophthalmology, vol. 15, no. 6, pp. 508-518, 2004.

[60] N. Shams and T. Ianchulev, "Role of vascular endothelial growth factor in ocular angiogenesis," Ophthalmology Clinics of North America, vol. 19, no. 3, pp. 335-344, 2006.

[61] D. B. Mendel, A. D. Laird, B. D. Smolich et al., "Development of SU5416, a selective small molecule inhibitor of VEGF receptor tyrosine kinase activity, as an anti-angiogenesis agent," Anti-Cancer Drug Design, vol. 15, no. 1, pp. 29-41, 2000.

[62] D. J. Kelly, D. Buck, A. J. Cox, Y. Zhang, and R. E. Gilbert, "Effects on protein kinase C- $\beta$ inhibition on glomerular vascular endothelial growth factor expression and endothelial cells in advanced experimental diabetic nephropathy," American Journal of Physiology, vol. 293, no. 2, pp. F565F574, 2007.

[63] R. Francese and P. Fiorina, "Immunological and regenerative properties of cord blood stem cells," Clinical Immunology, vol. 136, no. 3, pp. 309-322, 2010.

[64] C. P. McGuckin and N. Forraz, "Potential for access to embryonic-like cells from human umbilical cord blood," Cell Proliferation, vol. 41, no. 1, pp. 31-40, 2008.

[65] K. Naruse, Y. Hamada, E. Nakashima et al., "Therapeutic neovascularization using cord blood-derived endothelial progenitor cells for diabetic neuropathy," Diabetes, vol. 54, no. 6, pp. 1823-1828, 2005.

[66] M. F. Pittenger, A. M. Mackay, S. C. Beck et al., "Multilineage potential of adult human mesenchymal stem cells," Science, vol. 284, no. 5411, pp. 143-147, 1999.

[67] L. Sensebé and P. Bourin, "Mesenchymal stem cells for therapeutic purposes," Transplantation, vol. 87, no. 9, pp. S49-53, 2009.

[68] K. Le Blanc, C. Tammik, K. Rosendahl, E. Zetterberg, and O. Ringdén, "HLA expression and immunologic properties of differentiated and undifferentiated mesenchymal stem cells," Experimental Hematology, vol. 31, no. 10, pp. 890-896, 2003.

[69] E. Lombardo and O. Delarosa, "Modulation of adult mesenchymal stem cells activity by toll-like receptors: implications on therapeutic potential," Mediators of Inflammation, vol. 2010, Article ID 865601, 2010.

[70] A. Corcione, F. Benvenuto, E. Ferretti et al., "Human mesenchymal stem cells modulate B-cell functions," Blood, vol. 107, no. 1, pp. 367-372, 2006.

[71] M. Krampera, S. Glennie, J. Dyson et al., "Bone marrow mesenchymal stem cells inhibit the response of naive and memory antigen-specific T cells to their cognate peptide," Blood, vol. 101, no. 9, pp. 3722-3729, 2003.

[72] S. Glennie, I. Soeiro, P. J. Dyson, E. W. F. Lam, and F. Dazzi, "Bone marrow mesenchymal stem cells induce division arrest anergy of activated T cells," Blood, vol. 105, no. 7, pp. 28212827, 2005.

[73] B. Puissant, C. Barreau, P. Bourin et al., "Immunomodulatory effect of human adipose tissue-derived adult stem cells: comparison with bone marrow mesenchymal stem cells," British Journal of Haematology, vol. 129, no. 1, pp. 118-129, 2005.

[74] L. Cui, Y. Shuo, W. Liu, N. Li, W. Zhang, and Y. Cao, "Expanded adipose-derived stem cells suppress mixed lymphocyte reaction by secretion of prostaglandin E2," Tissue Engineering, vol. 13, no. 6, pp. 1185-1195, 2007.

[75] O. Delarosa, E. Lombardo, A. Beraza et al., "Requirement of IFN- $\gamma$-mediated indoleamine 2,3-dioxygenase expression in the modulation of lymphocyte proliferation by human adipose-derived stem cells," Tissue Engineering A, vol. 15, no. 10, pp. 2795-2806, 2009.

[76] X. X. Jiang, Y. Zhang, B. Liu et al., "Human mesenchymal stem cells inhibit differentiation and function of monocytederived dendritic cells," Blood, vol. 105, no. 10, pp. 41204126, 2005.

[77] G. M. Spaggiari, H. Abdelrazik, F. Becchetti, and L. Moretta, "MSCs inhibit monocyte-derived DC maturation and function by selectively interfering with the generation of immature DCs: central role of MSC-derived prostaglandin E2," Blood, vol. 113, no. 26, pp. 6576-6583, 2009.

[78] I. Rasmusson, O. Ringdén, B. Sundberg, and K. Le Blanc, "Mesenchymal stem cells inhibit the formation of cytotoxic 
T lymphocytes, but not activated cytotoxic T lymphocytes or natural killer cells," Transplantation, vol. 76, no. 8, pp. 12081213, 2003.

[79] N. Zhang, J. Li, R. Luo, J. Jiang, and J. A. Wang, "Bone marrow mesenchymal stem cells induce angiogenesis and attenuate the remodeling of diabetic cardiomyopathy," Experimental and Clinical Endocrinology and Diabetes, vol. 116, no. 2, pp. 104-111, 2008.

[80] Y. Wu, L. Chen, P. G. Scott, and E. E. Tredget, "Mesenchymal stem cells enhance wound healing through differentiation and angiogenesis," Stem Cells, vol. 25, no. 10, pp. 2648-2659, 2007.

[81] Z. Yang, K. Li, X. Yan, F. Dong, and C. Zhao, "Amelioration of diabetic retinopathy by engrafted human adipose-derived mesenchymal stem cells in streptozotocin diabetic rats," Graefe's Archive for Clinical and Experimental Ophthalmology, vol. 248, no. 10, pp. 1415-1422, 2010.

[82] T. Murohara, "Therapeutic vasculogenesis using human cord blood-derived endothelial progenitors," Trends in Cardiovascular Medicine, vol. 11, no. 8, pp. 303-307, 2001.

[83] I. Ahrens, H. Domeij, D. Topcic et al., "Successful in vitro expansion and differentiation of cord blood derived CD $34^{+}$ cells into early endothelial progenitor cells reveals highly differential gene expression," PLOS ONE, vol. 6, no. 8, 2011.

[84] T. Asahara, T. Murohara, A. Sullivan et al., "Isolation of putative progenitor endothelial cells for angiogenesis," Science, vol. 275, no. 5302, pp. 964-967, 1997.

[85] M. Hristov, W. Erl, and P. C. Weber, "Endothelial progenitor cells: mobilization, differentiation, and homing," Arteriosclerosis, Thrombosis, and Vascular Biology, vol. 23, no. 7, pp. 1185-1189, 2003.

[86] I. Arnaoutova, J. George, H. K. Kleinman, and G. Benton, "The endothelial cell tube formation assay on basement membrane turns 20: state of the science and the art," Angiogenesis, vol. 12, no. 3, pp. 267-274, 2009.

[87] L. S. Barcelos, C. Duplaa, N. Kränkel et al., "Human CD133+ progenitor cells promote the healing of diabetic ischemic ulcers by paracrine stimulation of angiogenesis and activation of Wnt signaling," Circulation Research, vol. 104, no. 9, pp. 1095-1102, 2009.

[88] P. Fiorina, G. Pietramaggiori, S. S. Scherer et al., "The mobilization and effect of endogenous bone marrow progenitor cells in diabetic wound healing," Cell Transplantation, vol. 19, no. 11, pp. 1369-1381, 2010.

[89] J. Asai, H. Takenaka, K. F. Kusano et al., “Topical sonic hedgehog gene therapy accelerates wound healing in diabetes by enhancing endothelial progenitor cell-mediated microvascular remodeling," Circulation, vol. 113, no. 20, pp. 2413-2424, 2006.

[90] J. O. Jeong, M. O. Kim, H. Kim et al., "Dual angiogenic and neurotrophic effects of bone marrow-derived endothelial progenitor cells on diabetic neuropathy," Circulation, vol. 119, no. 5, pp. 699-708, 2009.

[91] S. Ylä-Herttuala, T. T. Rissanen, I. Vajanto, and J. Hartikainen, "Vascular endothelial growth factors. Biology and current status of clinical applications in cardiovascular medicine," Journal of the American College of Cardiology, vol. 49, no. 10, pp. 1015-1026, 2007.

[92] D. Schrijvers, "Role of red blood cells in pharmacokinetics of chemotherapeutic agents," Clinical Pharmacokinetics, vol. 42, no. 9, pp. 779-791, 2003.

[93] J. Kastrup, “Therapeutic angiogenesis in ischemic heart disease: gene or recombinant vascular growth factor protein therapy?" Current Gene Therapy, vol. 3, no. 3, pp. 197-206, 2003.

[94] J. M. Isner, I. Baumgartner, G. Rauh et al., "Treatment of thromboangiitis obliterans (Buerger's disease) by intramuscular gene transfer of vascular endothelial growth factor: preliminary clinical results," Journal of Vascular Surgery, vol. 28, no. 6, pp. 964-975, 1998.

[95] J. M. Isner, A. Pieczek, R. Schainfeld et al., "Clinical evidence of angiogenesis after arterial gene transfer of phVEGF165 in patient with ischaemic limb," The Lancet, vol. 348, no. 9024, pp. 370-374, 1996.

[96] K. G. Shyu, H. Chang, B. W. Wang, and P. Kuan, "Intramuscular vascular endothelial growth factor gene therapy in patients with chronic critical leg ischemia," American Journal of Medicine, vol. 114, no. 2, pp. 85-92, 2003.

[97] D. Simovic, J. M. Isner, A. H. Ropper, A. Pieczek, and D. $\mathrm{H}$. Weinberg, "Improvement in chronic ischemic neuropathy after intramuscular phVEGF165 gene transfer in patients with critical limb ischemia," Archives of Neurology, vol. 58, no. 5, pp. 761-768, 2001.

[98] I. Kholová, S. Koota, N. Kaskenpää et al., "Adenovirus-mediated gene transfer of human vascular endothelial growth factor-D induces transient angiogenic effects in mouse hind limb muscle," Human Gene Therapy, vol. 18, no. 3, pp. 232244, 2007.

[99] S. Rajagopalan, M. Shah, A. Luciano, R. Crystal, and E. G. Nabel, "Adenovirus-mediated gene transfer of VEGF121 improves lower-extremity endothelial function and flow reserve," Circulation, vol. 104, no. 7, pp. 753-755, 2001.

[100] Y. H. Kusumanto, V. Van Weel, N. H. Mulder et al., "Treatment with intramuscular vascular endothelial growth factor gene compared with placebo for patients with diabetes mellitus and critical limb ischemia: a double-blind randomized trial," Human Gene Therapy, vol. 17, no. 6, pp. 683-691, 2006.

[101] T. A. Khan, F. W. Sellke, and R. J. Laham, "Gene therapy progress and prospects: therapeutic angiogenesis for limb and myocardial ischemia," Gene Therapy, vol. 10, no. 4, pp. 285-291, 2003.

[102] A. Germani, C. Di Campli, G. Pompilio, P. Biglioli, and M. C. Capogrossi, "Regenerative therapy in peripheral artery disease," Cardiovascular Therapeutics, vol. 27, no. 4, pp. 289304, 2009.

[103] S. Nikol, I. Baumgartner, E. Van Belle et al., "Therapeutic angiogenesis with intramuscular NV1FGF improves amputation-free survival in patients with critical limb ischemia," Molecular Therapy, vol. 16, no. 5, pp. 972-978, 2008.

[104] I. Baumgartner, N. Chronos, A. Comerota et al., "Local gene transfer and expression following intramuscular administration of FGF-1 plasmid DNA in patients with critical limb ischemia," Molecular Therapy, vol. 17, no. 5, pp. 914-921, 2009.

[105] F. G. R. Fowkes and J. F. Price, "Gene therapy for critical limb ischaemia: the TAMARIS trial," The Lancet, vol. 377, no. 9781, pp. 1894-1896, 2011.

[106] P. Dell'Era, M. Belleri, H. Stabile, M. L. Massardi, D. Ribatti, and M. Presta, "Paracrine and autocrine effects of fibroblast growth factor-4 in endothelial cells," Oncogene, vol. 20, no. 21, pp. 2655-2663, 2001.

[107] A. Praidou, S. Androudi, P. Brazitikos, G. Karakiulakis, E. Papakonstantinou, and S. Dimitrakos, "Angiogenic growth factors and their inhibitors in diabetic retinopathy," Current Diabetes Reviews, vol. 6, no. 5, pp. 304-312, 2010.

[108] R. Morishita, S. Nakamura, S. I. Hayashi et al., "Therapeutic angiogenesis induced by human recombinant hepatocyte 
growth factor in rabbit hind limb ischemia model as cytokine supplement therapy," Hypertension, vol. 33, no. 6, pp. 13791384, 1999.

[109] Y. Taniyama, R. Morishita, M. Aoki et al., "Therapeutic angiogenesis induced by human hepatocyte growth factor gene in rat and rabbit hindlimb ischemia models: preclinical study for treatment of peripheral arterial disease," Gene Therapy, vol. 8, no. 3, pp. 181-189, 2001.

[110] R. J. Powell, M. Simons, F. O. Mendelsohn et al., "Results of a double-blind, placebo-controlled study to assess the safety of intramuscular injection of hepatocyte growth factor plasmid to improve limb perfusion in patients with critical limb ischemia," Circulation, vol. 118, no. 1, pp. 58-65, 2008.

[111] D. J. Ceradini, A. R. Kulkarni, M. J. Callaghan et al., "Progenitor cell trafficking is regulated by hypoxic gradients through HIF-1 induction of SDF-1," Nature Medicine, vol. 10, no. 8, pp. 858-864, 2004.

[112] M. Bosch-Marce, H. Okuyama, J. B. Wesley et al., "Effects of aging and hypoxia-inducible factor-1 activity on angiogenic cell mobilization and recovery of perfusion after limb ischemia," Circulation Research, vol. 101, no. 12, pp. 13101318, 2007.

[113] T. H. Patel, H. Kimura, C. R. Weiss, G. L. Semenza, and L. V. Hofmann, "Constitutively active HIF- $1 \alpha$ improves perfusion and arterial remodeling in an endovascular model of limb ischemia," Cardiovascular Research, vol. 68, no. 1, pp. 144154, 2005.

[114] S. Rajagopalan, J. Olin, S. Deitcher et al., "Use of a constitutively active hypoxia-inducible factor- $1 \alpha$ transgene as a therapeutic strategy in no-option critical limb ischemia patients: phase I dose-escalation experience," Circulation, vol. 115, no. 10, pp. 1234-1243, 2007.

[115] M. Meloni, A. Caporali, G. Graiani et al., "Nerve growth factor promotes cardiac repair following myocardial infarction," Circulation Research, vol. 106, no. 7, pp. 1275-1284, 2010.

[116] C. Emanueli, M. B. Salis, A. Pinna, G. Graiani, L. Manni, and P. Madeddu, "Nerve growth factor promotes angiogenesis and arteriogenesis in ischemic hindlimbs," Circulation, vol. 106, no. 17, pp. 2257-2262, 2002.

[117] N. Hansen-Algenstaedt, P. Algenstaedt, C. Schaefer et al., "Neural driven angiogenesis by overexpression of nerve growth factor," Histochemistry and Cell Biology, vol. 125, no. 6, pp. 637-649, 2006.

[118] M. J. Park, H. J. Kwak, H. C. Lee et al., "Nerve growth factor induces endothelial cell invasion and cord formation by promoting matrix metalloproteinase- 2 expression through the phosphatidylinositol 3-kinase/Akt signaling pathway and AP-2 transcription factor," Journal of Biological Chemistry, vol. 282, no. 42, pp. 30485-30496, 2007.

[119] M. Meloni, B. Descamps, A. Caporali et al., "Nerve growth factor gene therapy using adeno-associated viral vectors prevents cardiomyopathy in type 1 diabetic mice," Diabetes, vol. 61, no. 1, pp. 229-240, 2012.

[120] C. Emanueli and P. Madeddu, "Human tissue kallikrein: a new bullet for the treatment of ischemia," Current Pharmaceutical Design, vol. 9, no. 7, pp. 589-597, 2003.

[121] P. Porcu, C. Emanueli, M. Kapatsoris, J. Chao, L. Chao, and P. Madeddu, "Reversal of angiogenic growth factor upregulation by revascularization of lower limb ischemia," Circulation, vol. 105, no. 1, pp. 67-72, 2002.

[122] R. S. Smith, L. Gao, L. Chao, and J. Chao, “Tissue kallikrein and kinin infusion promotes neovascularization in limb ischemia," Biological Chemistry, vol. 389, no. 6, pp. 725-730, 2008.
[123] C. Emanueli, A. Zacheo, A. Minasi et al., "Adenovirus-mediated human tissue kallikrein gene delivery induces angiogenesis in normoperfused skeletal muscle," Arteriosclerosis, Thrombosis, and Vascular Biology, vol. 20, no. 11, pp. 2379$2385,2000$.

[124] C. Emanueli, M. B. Salis, A. Pinna et al., "Prevention of diabetes-induced microangiopathy by human tissue kallikrein gene transfer," Circulation, vol. 106, no. 8, pp. 993-999, 2002. 


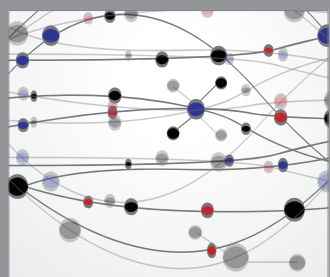

The Scientific World Journal
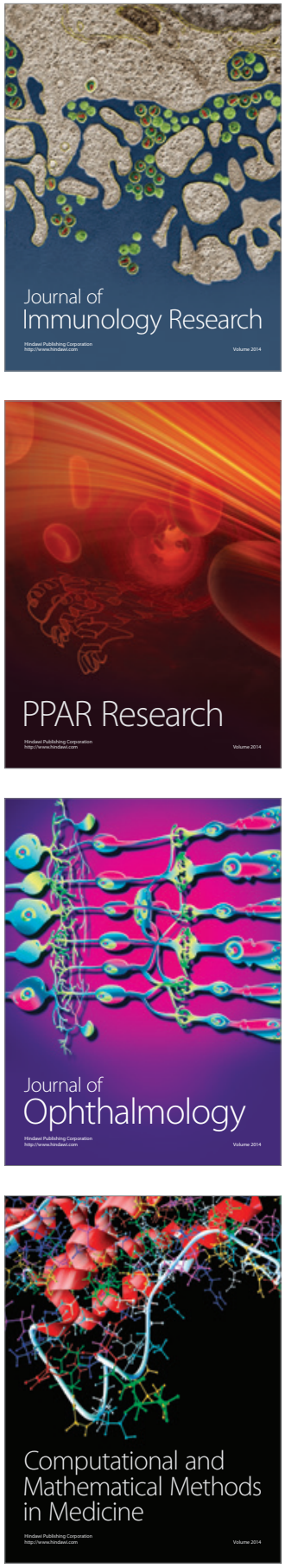

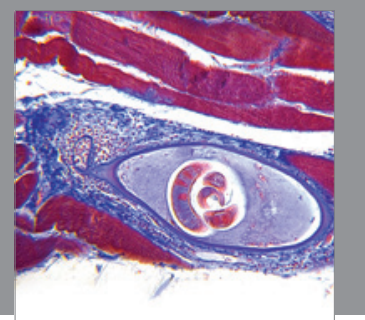

Gastroenterology

Research and Practice
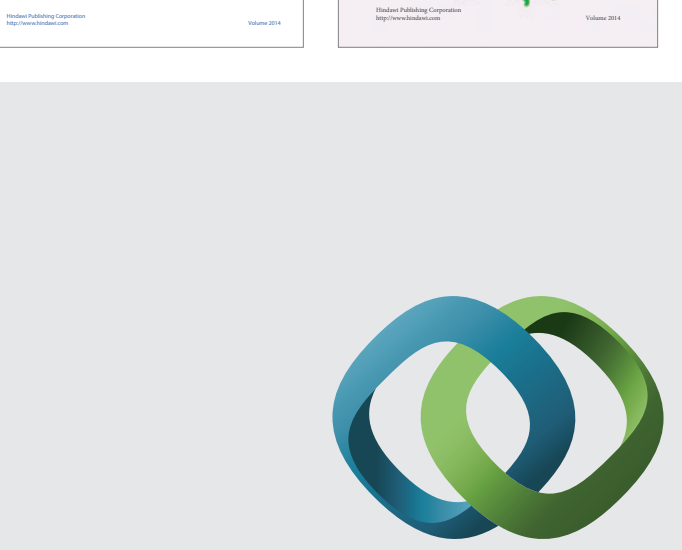

\section{Hindawi}

Submit your manuscripts at

http://www.hindawi.com
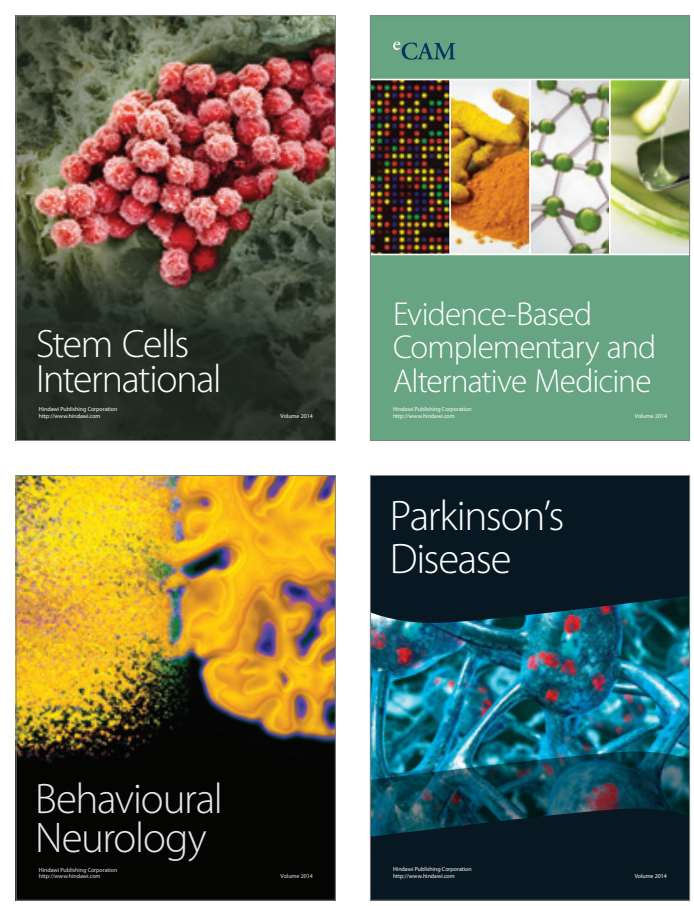

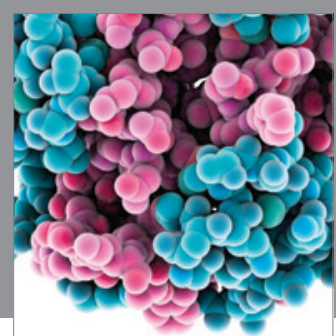

Journal of
Diabetes Research

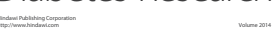

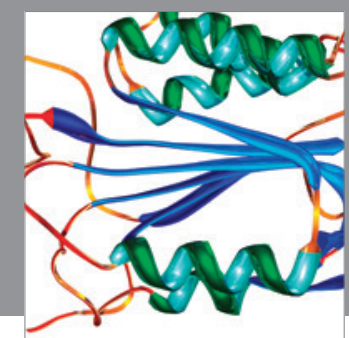

Disease Markers
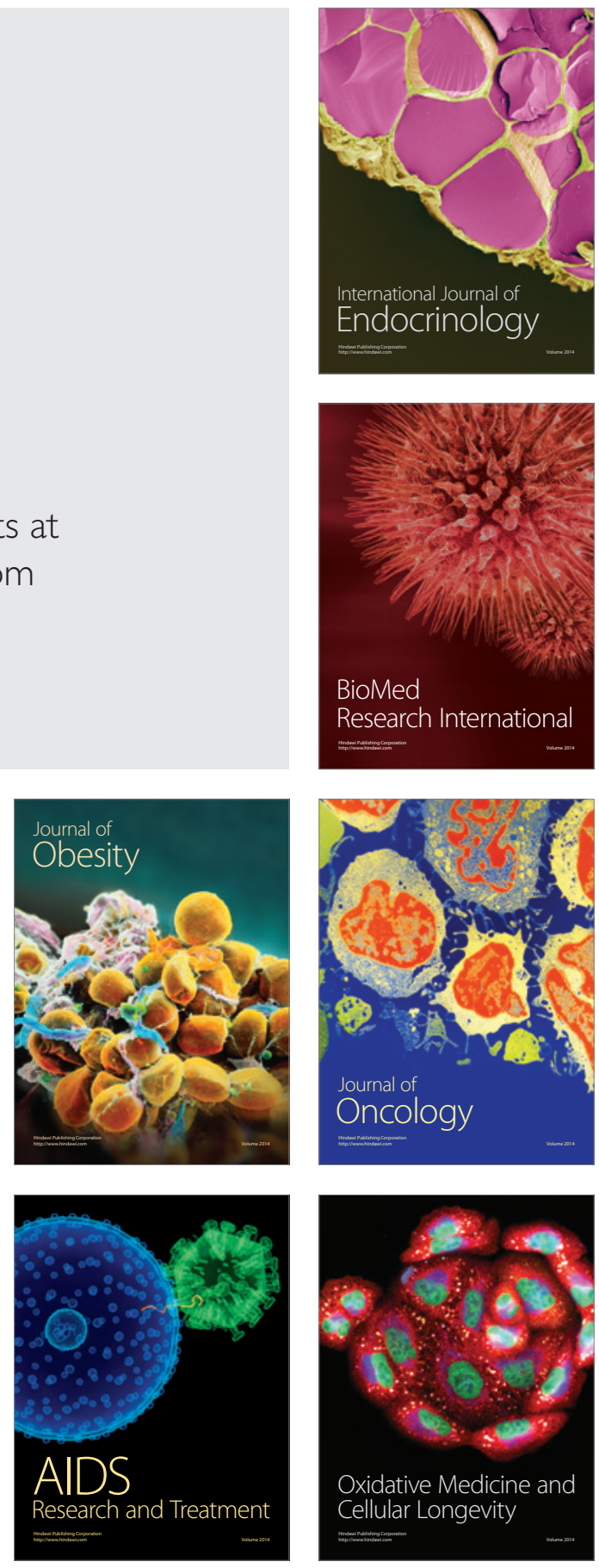